\title{
Effects of Ion and Protic Solvent on Nucleophilic Aromatic Substitution $\left(S_{N} A r\right)$ Reactions
}

\author{
Sungwoo Park and Sungyul Lee* \\ Department of Applied Chemistry, Kyung Hee University, Kyungki 446-701, Korea. ${ }^{*}$ E-mail: sylee@khu.ac.kr \\ Received May 10, 2010, Accepted July 26, 2010
}

\begin{abstract}
We investigate the mechanism of $\mathrm{S}_{\mathrm{N}} A r$ fluorination reactions under the influence of protic solvents and ions. We find that counterion or protic solvent alone retards the $S_{N} A r$ reactions, but together they may promote the reaction. In this mechanism, the protic solvent acts on the counterion as a Lewis base, and the nucleophile reacts as an ion pair. We also show that an anion (mesylate) may exhibit catalytic effects, suggesting the role of ionic liquids for accelerating the $\mathrm{S}_{\mathrm{N}} \mathrm{Ar}$ reactions.
\end{abstract}

Key Words: Ion, Protic solvents, $\mathrm{S}_{\mathrm{N}} \mathrm{Ar}$

\section{Introduction}

Nucleophilic substitution, which has not been popular for aromatic reactions, proved much more efficient for producing 18[F]-labeled biomolecules than electrophilic aromatic substitution. ${ }^{1-7}$ Although the fluoride anion is very reactive in gas phase in nucleophilic processes, the reactivity drops dramatically in solution phase due to strong effects of counterion (cation) and solvent. It has been considered that protic solvents retard the $\mathrm{S}_{\mathrm{N}} 2$ reactions because of hydrogen bonding with the nucleophile. Recently, however, Chi and co-workers ${ }^{8}$ observed that bulky protic solvents such as tert-butyl alcohol can be very efficient for $\mathrm{S}_{\mathrm{N}} 2$ reactions, in stark contrast with conventional belief. To elucidate this observation, Lee and co-workers ${ }^{9-12}$ proposed a new $\mathrm{S}_{\mathrm{N}} 2$ mechanism, in which the nucleophile reacts in the form of an ion pair $\left(\mathrm{M}^{+} \mathrm{X}\right)$ and the protic solvent interacts as a Lewis base with the counterion rather than with the nucleophile.

Pliego and Piló-Veloso ${ }^{13}$ recently suggested in their computational work of $\mathrm{S}_{\mathrm{N}} \mathrm{Ar}$ reactions that the more $\mathrm{F}^{-}$ion is naked, the more facilitated is the $\mathrm{S}_{\mathrm{N}} \mathrm{Ar}$ reaction. In this conventional wisdom for nucleophilic aromatic substitution reaction, hydration is sure to retard the reaction through hydrogen bonding with the nucleophile. In the present work, we study whether the protic solvent could be efficient for $\mathrm{S}_{\mathrm{N}} \mathrm{Ar}$ reactions. We systematically analyze the influence of cation (alkali metal ions $\mathrm{Na}^{+}$and $\mathrm{Cs}^{+}$) and protic solvent (water) on the $\mathrm{S}_{\mathrm{N}} \mathrm{Ar}$ reactions $\left[\mathrm{M}^{+} \mathrm{F}^{-}+\right.$nitrobenzene $+\mathrm{nH}_{2} \mathrm{O} \rightarrow$ fluorobenzene $+\mathrm{M}^{+} \mathrm{NO}_{2}^{-}+$ $\left.\mathrm{nH}_{2} \mathrm{O}\left(\mathrm{M}^{+}=\mathrm{Na}^{+}, \mathrm{Cs}^{+}, \mathrm{n}=0,2\right)\right]$ depicted in Scheme 1. We investigate the mechanistic process of $\mathrm{S}_{\mathrm{N}} \mathrm{Ar}$ fluorination by quantum chemical methods. We calculate and compare the reaction barriers of $\mathrm{S}_{\mathrm{N}} \mathrm{Ar}$ reactions under the influence of counterion and/or protic solvent, and find that cation or water molecule (acting as Lewis acid) alone retards the reaction considerably.

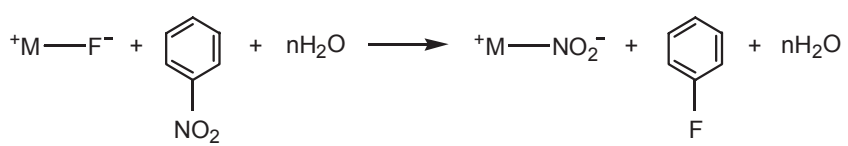

Scheme 1. $\mathrm{S}_{\mathrm{N}}$ Ar fluorination by the salt MF under the influence of water molecules
These findings are in line with conventional thinking of the role of cation and protic solvent in $\mathrm{S}_{\mathrm{N}} \mathrm{Ar}$ reactions. We propose, however, an alternative mechanism in which cation and protic solvent molecules cooperate to accelerate the $\mathrm{S}_{\mathrm{N}} \mathrm{Ar}$ reaction. In this situation, solvent molecules are shielded from the nucleophilie by the cation, acting as a Lewis base on the cation to reduce its unfavorable Coulombic influence on the nucleophile. Based on this observation, we also propose a mechanism in which solvent anion (for example, mesylate in ionic liquid) may promote the $\mathrm{S}_{\mathrm{N}} \mathrm{Ar}$ process.

\section{Computational Methods}

Density functional theory method (MPW1K) is employed with the $6-311++G^{* *}$ basis set and the effective core potential for Cs (Hay-Wadt VDZ(n+1)), ${ }^{14}$ as implemented in GAUSSIAN 03 set of programs. ${ }^{15}$ Stationary structures are confirmed by ascertaining that all the harmonic frequencies are real. Structures of the transition state (TS) are obtained by verifying that one and only one of the harmonic frequencies is imaginary, and also by carrying out the intrinsic reaction coordinate (IRC) analysis along the reaction pathway. Zero point energies (ZPE) are taken into account, and default criteria are used for all optimizations.

\section{Results}

Figure 1 presents the gas-phase $\mathrm{S}_{\mathrm{N}} \mathrm{Ar}$ fluorination $\left[\mathrm{F}^{-}+\right.$nitrobenzene $\rightarrow$ fluorobenzene $\left.+\mathrm{NO}_{2}^{-}\right]$. One of the central questions concerning the $\mathrm{S}_{\mathrm{N}} \mathrm{Ar}$ process is whether the reaction proceeds in a single step with a transition state, or in a two-step mechanism with an intermediate. Our calculations demonstrate that the $\mathrm{S}_{\mathrm{N}} \mathrm{Ar}$ reaction $\mathrm{F}^{-}$with nitrobenzene occurs in a single-step without formation of a stable $\sigma$-complex, in line with the agree with the report by Glukhovtsev. ${ }^{4}$ The pre-reaction complex is very stable with the energy lower by $\sim 16 \mathrm{kcal} / \mathrm{mol}$ than that of the separate reactants. The activation barrier is calculated to be very low ( $\sim 4 \mathrm{kcal} / \mathrm{mol})$, indicating that the reaction is instantaneous, in the absence of counterion and solvent.

Figure 2 presents the effects of hydration. It models the aque- 


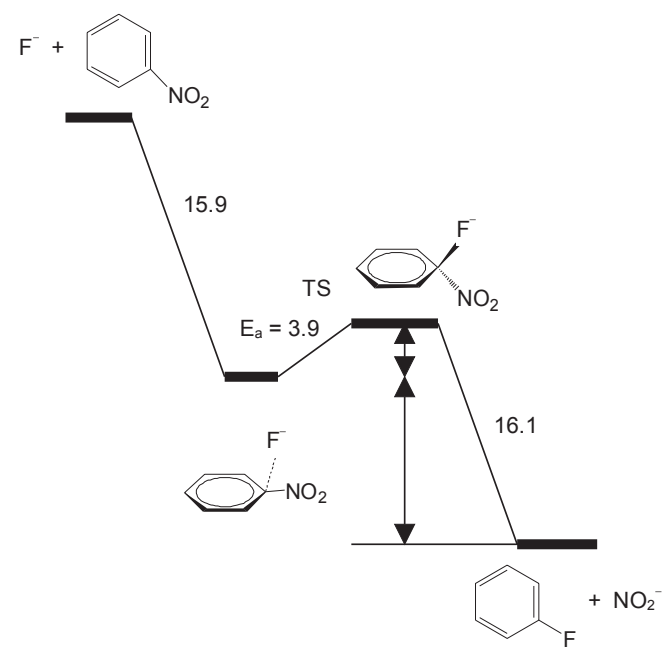

Figure 1. Energy profile and mechanism of the reaction $\left[\mathrm{F}^{-}+\right.$nitrobenzene $\rightarrow$ fluorobenzene $\left.+\mathrm{NO}_{2}^{-}\right]$. Energy in $\mathrm{kcal} / \mathrm{mol}$.

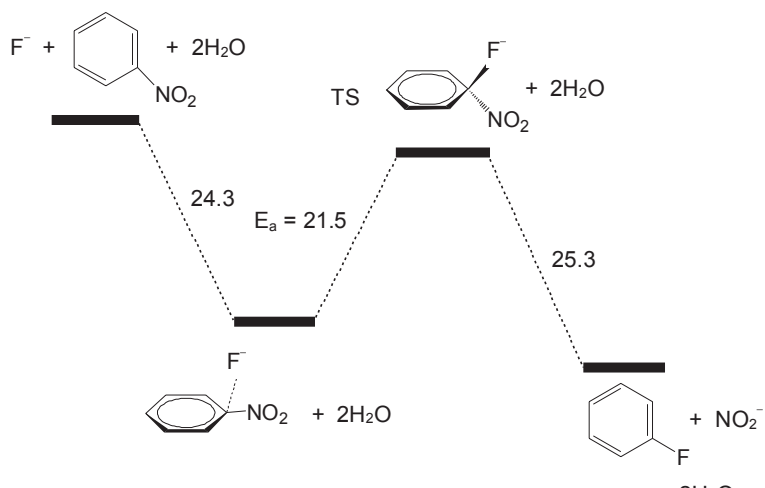

Figure 2. Energy profile and mechanism of the reaction $\left[\mathrm{F}^{-}+\right.$nitrobenzene $+2 \mathrm{H}_{2} \mathrm{O} \rightarrow$ fluorobenzene $+\mathrm{NO}_{2}^{-}+2 \mathrm{H}_{2} \mathrm{O}$ ]. Energy in $\mathrm{kcal} / \mathrm{mol}$.

ous solution phase as a cluster of water molecules to explicitly probe the effects of water molecules on the reaction barrier. In the most stable pre-reaction complex, the two water molecules, nitro and fluoride ion form a ring through hydrogen bonding. A water molecule interacts with $\mathrm{F}^{-}$, while another binds to the leaving group. The activation barrier significantly increases to $\sim 21.5 \mathrm{kcal} / \mathrm{mol}$, clearly demonstrating the retarding effects of water.

In conventional concept of $\mathrm{S}_{\mathrm{N}} \mathrm{Ar}$ reactions, counterions (cations) are considered to be harmful due to strong Coulombic influence on the nucleophile. Figure 3(a) presents the reaction $\left[\mathrm{Na}^{+} \mathrm{F}^{-}+\right.$nitrobenzene $\rightarrow$ fluorobenzene $\left.+\mathrm{Na}^{+} \mathrm{NO}_{2}^{-}\right]$in the absence of solvating water molecules. In the pre-reaction complex, the ion pair $\mathrm{Na}^{+} \mathrm{F}^{-}$and the nitro group are arranged in a coplanar fashion. This is quite different from the pre-reaction complexes depicted in Figure 1 and Figure 2, in which the nucleophile $\mathrm{F}^{-}$is located off the phenyl ring. It seems that the counterion $\mathrm{Na}^{+}$bridges $\mathrm{F}^{-}$and the leaving group $\mathrm{NO}_{2}$ in the pre-reaction complex in Figure 3(a), rendering a stronger interaction between $\mathrm{F}^{-}, \mathrm{NO}_{2}$, and the hydrogen atom in a planar configuration. Whereas the ion pair locates perpendicular to the benzene ring in the transition state. Due to strong Coulombic

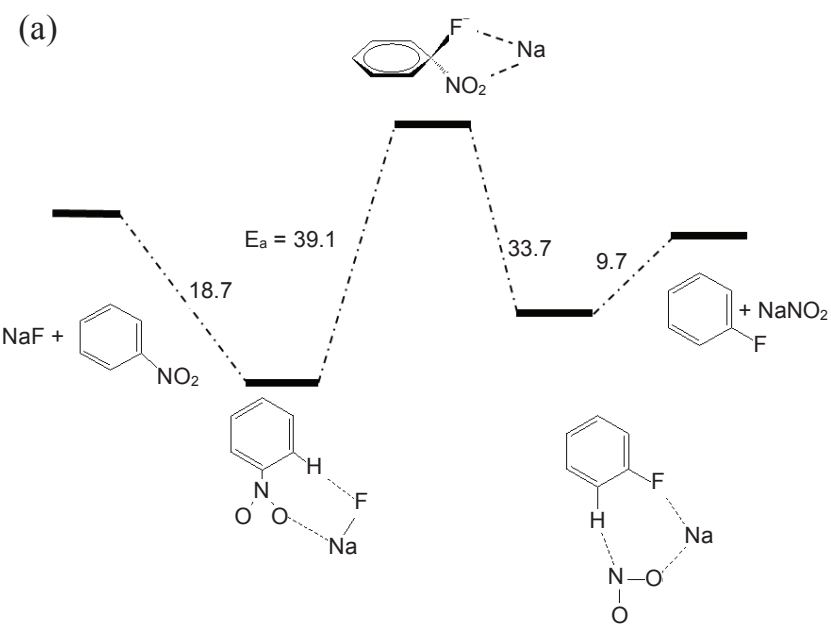

(b)

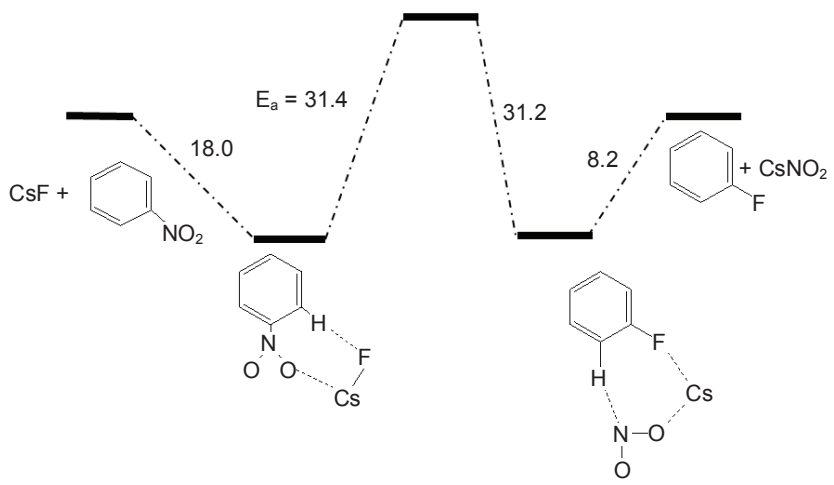

Figure 3. Energy profile and mechanism of the reactions $\left[\mathrm{M}^{+} \mathrm{F}^{-}+\right.$nitrobenzene $\rightarrow$ fluorobenzene $+\mathrm{M}^{+} \mathrm{NO}_{2}^{-}$] (a) $\mathrm{M}=\mathrm{Na}$ (b) $\mathrm{M}=$ Cs. Energy in $\mathrm{kcal} / \mathrm{mol}$.

interaction between $\mathrm{Na}^{+}$and $\mathrm{F}^{-}$, the activation barrier dramatically increases to $\sim 39.1 \mathrm{kcal} / \mathrm{mol}$. Figure 3 (b) presents the corresponding reaction $\left[\mathrm{Cs}^{+} \mathrm{F}^{-}+\right.$nitrobenzene $\rightarrow$ fluorobenzene + $\mathrm{CsNO}_{2}$ ], in which the larger and more polarizable counterion $\mathrm{Cs}^{+}$is used. The activation barrier is much smaller $(\sim 31.4 \mathrm{kcal} /$ $\mathrm{mol})$, as a result of weaker Coulombic influence of $\mathrm{Cs}^{+}$on $\mathrm{F}^{-}$.

Observing that the protic solvent molecules or the cation tend to increase (decrease) the barrier (rate) of the $\mathrm{S}_{\mathrm{N}} \mathrm{Ar}$ reaction, one may ask: what would the effects of protic solvent be when partaking in combination with cation? Figure 4(a) illustrates the situation under the influence of $\mathrm{Na}^{+}$and two water molecules. In the pre-reaction complex, one water molecule bridges $\mathrm{Na}^{+}$and $\mathrm{NO}_{2}^{-}$, partially neutralizing the Coulombic attractive force by $\mathrm{Na}^{+}$on $\mathrm{F}^{-}$and also assisting the detachment of the leaving group $\mathrm{NO}_{2}^{-}$. It is worth noting that $\mathrm{F}^{-}$is located again off the phenyl ring plane in the pre-reaction complexes in Figure 4(a) due the influence of the two water molecules. The nucleophile $\mathrm{F}^{-}$distances away from the hydrogen atom and the counterion $\mathrm{Na}^{+}$, attacking the carbon atom and removing the leaving group.

The combined efforts of the water molecules and the counterion now lower the barrier significantly (by $12.6 \mathrm{kcal} / \mathrm{mol}$ ) 

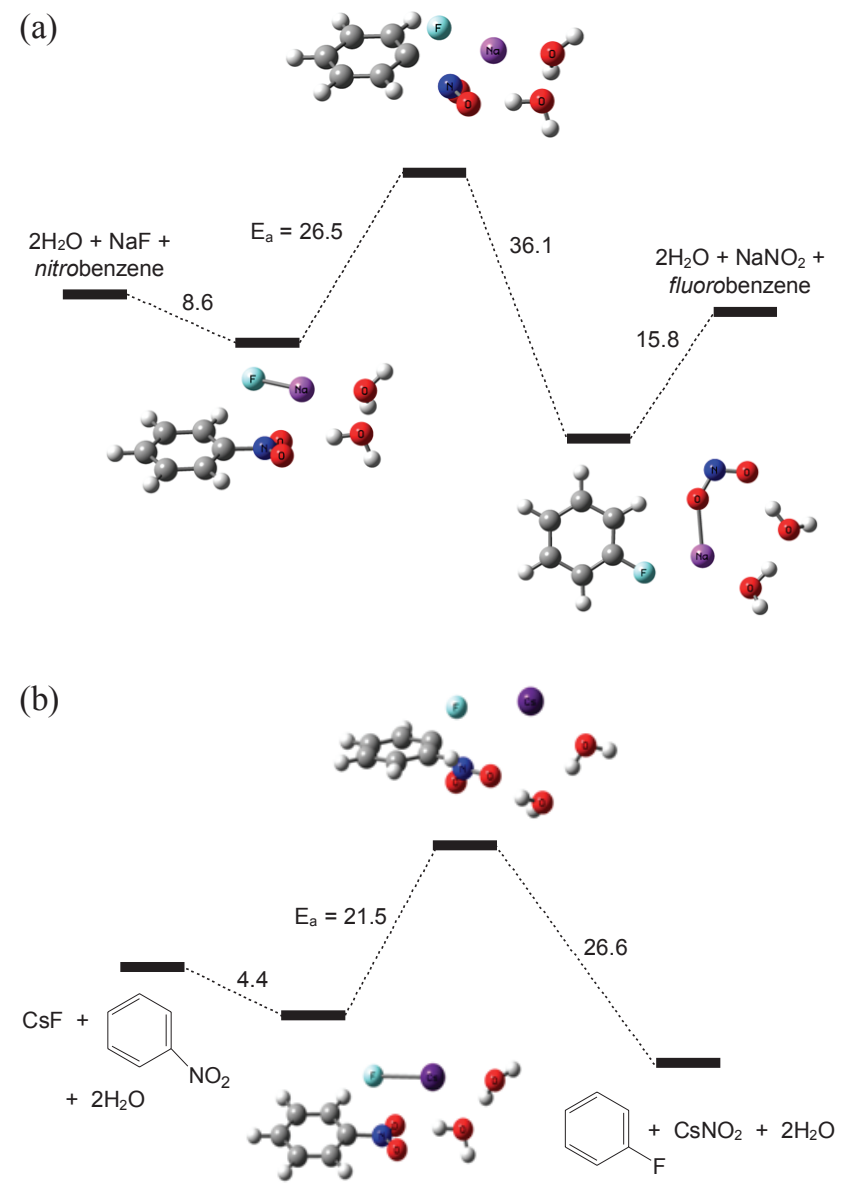

Figure 4. Energy profile and mechanism of the reaction $\left[\mathrm{M}^{+} \mathrm{F}^{-}+\right.$ nitrobenzene $+2 \mathrm{H}_{2} \mathrm{O} \rightarrow$ fluorobenzene $+\mathrm{M}^{+} \mathrm{NO}_{2}{ }^{-}+2 \mathrm{H}_{2} \mathrm{O}$ ] (a) $\mathrm{M}=$ $\mathrm{Na}$ (b) $\mathrm{M}=$ Cs. Energy in $\mathrm{kcal} / \mathrm{mol}$.

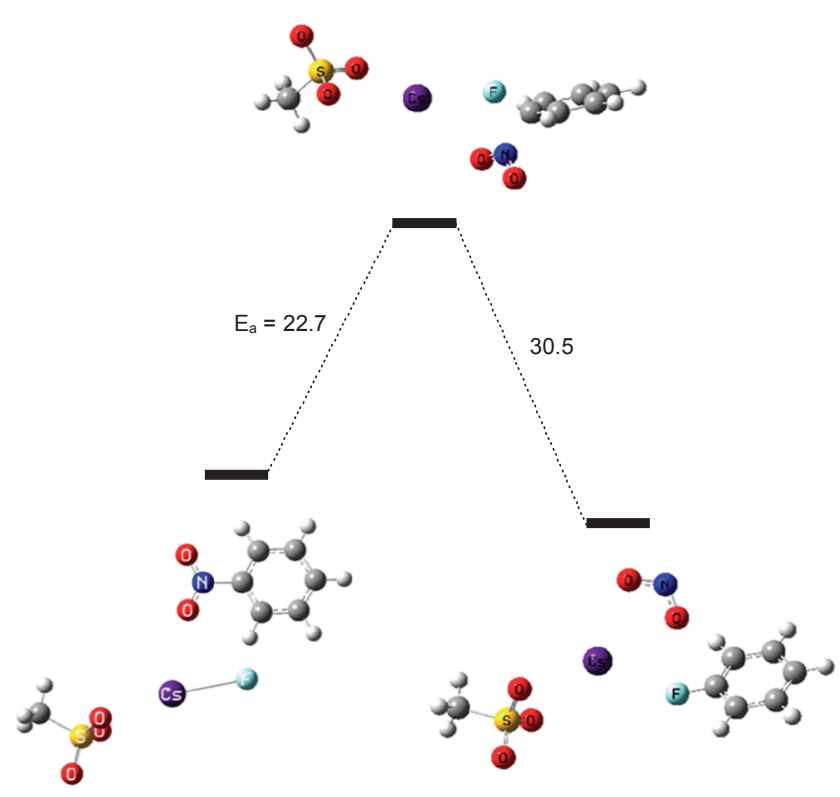

Figure 5. Energy profile and the mechanism of the reaction $\left[\mathrm{Cs}^{+} \mathrm{F}^{-}+\right.$ nitrobenzene + mesylate $\rightarrow$ fluorobenzene $+\mathrm{Cs}^{+} \mathrm{NO}_{2}^{-}+$mesylate $]$. Energy in $\mathrm{kcal} / \mathrm{mol}$. to $\sim 26.5 \mathrm{kcal} / \mathrm{mol}$. Figure 4 (b) presents the similar reaction $\left[\mathrm{Cs}^{+} \mathrm{F}^{-}+\right.$nitrobenzene $+2 \mathrm{H}_{2} \mathrm{O} \rightarrow$ fluorobenzene $+\mathrm{Cs}^{+} \mathrm{NO}_{2}^{-}+$ $2 \mathrm{H}_{2} \mathrm{O}$ ]. In this case, the activation barrier is further lowered to $\sim 21.5 \mathrm{kcal} / \mathrm{mol}$. Therefore, our calculated results imply that when the nucleophile reacts as an ion-pair $\left(\mathrm{Na}^{+} \mathrm{F}^{-}\right.$or $\left.\mathrm{Cs}^{+} \mathrm{F}^{-}\right)$ under the influence of water molecules, the synergetic effects of the cation and protic solvent may help to reduce the barrier significantly, suggesting a possible means of promoting the $\mathrm{S}_{\mathrm{N}} \mathrm{Ar}$ reaction rates by deliberately choosing the counterion and solvent.

If protic solvents could promote the $\mathrm{S}_{\mathrm{N}} \mathrm{Ar}$ reaction by acting as a Lewis base, solvent anions may also function in a similar fashion. The ion-pair $\mathrm{S}_{\mathrm{N}} \mathrm{Ar}$ reaction $\left[\mathrm{Cs}^{+} \mathrm{F}^{-}+\right.$nitrobenzene $\rightarrow$ $\mathrm{Cs}^{+} \mathrm{NO}_{2}^{-}+$fluorobenzene] under the influence of a mesylate anion $\mathrm{CH}_{3} \mathrm{SO}_{3}{ }^{-}$is depicted in Figure 5. The calculated activation barrier is $\sim 22.7 \mathrm{kcal} / \mathrm{mol}$, similar to that of the reaction in water, indicating that the anion may also be employed as a promoter of $\mathrm{S}_{\mathrm{N}} \mathrm{Ar}$ reactions. Since the ionic liquids would be a natural source of solvent anion, prudent design and use of ionic liquids may be useful to facilitate the $\mathrm{S}_{\mathrm{N}} \mathrm{Ar}$ reactions, as exemplified by Welton. ${ }^{16}$

In conclusion, we demonstrated by quantum chemical calculations that the combined effects of counterion and protic solvent may accelerate the $S_{N} A r$ reactions. By examining the influence of a mesylate anion, we also suggested that the ionic liquids can be employed to facilitate the $\mathrm{S}_{\mathrm{N}} \mathrm{Ar}$ reactions.

Acknowledgments. This work was supported by Kyung Hee University (2008).

\section{References}

1. Miller, P. W.; Long, N. J.; Vilar, R.; Gee, A. D. Angew. Chem. Int. Ed. 2008, 47, 8998.

2. Manka, J. T.; Mckenzle, V. C.; Kaszynski, P. J. Org. Chem. 2004, 69, 1967.

3. Peishoff, C. E.; Jorgensen, W. L. J. Org. Chem. 1985, 50, 1056.

4. Glukhovtsev, M. N.; Bach, R. D.; Lalter, S. J. Org. Chem. 1997, 62, 4036.

5. Acevedo, O.; Jorgensen, W. L. Org. Lett. 2004, 6, 2881.

6. Adam, C. G.; Fortunato, G. G.; Mancini, P. M. J. Phys. Org. Chem. 2009, 22, 460 .

7. (a) Terrier, F. Chem. Rev. 1982, 82, 77. (b) Ermert, J.; Hocke, C.; Ludwig, T.; Gail, R.; Coenen, H. H. J. Label. Compd. Radiopharm 2004, 47, 429. (c) Pawlas, J.; Vedsø, P.; Jakobsen, P.; Huusfeldt, P. O.; Begtrup, M. J. Org. Chem. 2002, 67, 585.

8. Kim, D.-W.; Ahn, D.-S.; Oh, Y.-H.; Lee, S.; Kil, H.-S.; Oh, S.-J.; Lee, S.-J.; Kim, J.-S.; Ryu, J.-S.; Moon, D.-H.; Chi, D.-Y. J. Am. Chem. Soc. 2006, 128, 16394.

9. Oh, Y.-H.; Ahn, D.-S.; Chung, S.-Y.; Jeon, J.-H.; Park, S.-W.; Oh, S. J.; Kim, D. W.; Kil, H. S.; Chi, D. Y.; Lee, S. J. Phys. Chem. A 2007, 111, 10152 .

10. Lee, S.-S.; Kim, H.-S.; Hwang, T.-K.; Oh, Y.-H.; Park, S.-W.; Lee, S.; Lee, B. S.; Chi, D. Y. Org. Lett. 2008, 10, 61.

11. Lee, J.-W.; Yan, H.; Jang, H.-B.; Kim, H.-K.; Park, S.-W.; Lee, S.; Chi, D.-Y.; Song, C.-E. Angew. Chem. Int. Ed. 2009, 48, 7683.

12. Im, S.; Jang, S.-W.; Kim, H.-R.; Oh, Y.-H.; Park, S.-W.; Lee, S.; Chi, D.-Y. J. Phys. Chem. A 2009, 113, 3685.

13. Pliego, J. R.; Piló-Veloso, D. Phys. Chem. Chem. Phys. 2008, 10, 1118.

14. Hay, P. J.; Wadt, W. R. J. Chem. Phys. 1985, 82, 299.

15. Frisch, M. J.; Trucks, G. W.; Schlegel, H. B.; Scuseria, G. E.; Robb, M. A.; Cheeseman, J. R.; Montgomery, J. A., Jr.; Vreven, T.; Ku- 
din, K. N.; Burant, J. C.; Millam, J. M.; Iyengar, S. S.; Tomasi, J.; Barone, V.; Mennucci, B.; Cossi, M.; Scalmani, G.; Rega, N.; Petersson, G. A.; Nakatsuji, H.; Hada, M.; Ehara, M.; Toyota, K.; Fukuda, R.; Hasegawa, J.; Ishida, M.; Nakajima, T.; Honda, Y.; Kitao, O.; Nakai, H.; Klene, M.; Li, X.; Knox, J. E.; Hratchian, H. P.; Cross, J. B.; Bakken, V.; Adamo, C.; Jaramillo, J.; Gomperts, R.; Stratmann, R. E.; Yazyev, O.; Austin, A. J.; Cammi, R.; Pomelli, C.; Ochterski, J. W.; Ayala, P. Y.; Morokuma, K.; Voth, G. A.; Salvador, P.; Dannenberg, J. J.; Zakrzewski, V. G.; Dapprich, S.;
Daniels, A. D.; Strain, M. C.; Farkas, O.; Malick, D. K.; Rabuck, A. D.; Raghavachari, K.; Foresman, J. B.; Ortiz, J. V.; Cui, Q.; Baboul, A. G.; Clifford, S.; Cioslowski, J.; Stefanov, B. B.; Liu, G.; Liashenko, A.; Piskorz, P.; Komaromi, I.; Martin, R. L.; Fox, D. J.; Keith, T.; Al-Laham, M. A.; Peng, C. Y.; Nanayakkara, A.; Challacombe, M.; Gill, P. M. W.; Johnson, B.; Chen, W.; Wong, M. W.; Gonzalez, C.; Pople, J. A. Gaussian 03; Gaussian, Inc.: Wallingford, CT, 2004.

16. Welton, T. Chem. Rev. 1999, 99, 2071. 